\title{
Effect of the Addition of Sugar Cane Bagasse Ash on the Compaction Properties of a Granular Material Type Hydraulic Base
}

\author{
Laura Landa-Ruiz, Sabino Márquez-Montero, Griselda Santiago-Hurtado, Victor Moreno-Landeros, \\ José Manuel Mendoza-Rangel, and Miguel Angel Baltazar-Zamora
}

\begin{abstract}
In the present investigation 8 soil samples were studied, with additions of 5 and $7 \%$ of addition of sugar Cane Bagasse Ash (SCBA), Portland Cement (PC) and combinations of these in different proportions. The characterization and classification of the study soil was carried out, determining the Natural Humidity, Granulometric Curve, Consistency Limits, soil classification according to the Unified Soil Classification System (USCS) and AASHTO compaction. The results show that the use of the SCBA is viable to significantly improve the physical properties of the granular soil type Hydraulic Base, The partial substitution of SCBA for PC according to the results can be considered that it would contribute to more durable and therefore economical roads. In addition to contributing to the reduction in cement consumption, which would imply a decrease in the release of $\mathrm{CO}_{2}$ into the atmosphere due to the manufacture of Portland Cement.
\end{abstract}

Index Terms - SCBA; Hydraulic Base; Compaction Properties.

\section{INTRODUCTION}

The problem of climate change is closely linked to the type of development, since greenhouse gas emissions are one of the consequences of patterns of economic growth that affect the environment and society [1]. Portland Cement (PC), which is the most used construction material in the world and that its manufacture, in addition to requiring more than $4000 \mathrm{KJ}$ per ton of cement, emits between $850 \mathrm{~kg}$ to $1000 \mathrm{~kg}$ of $\mathrm{CO}_{2}$ per ton of Portland cement produced, having in the year 2012 a world production of Portland Cement of more than 3,800,000 tons worldwide, with its respective emission of at least $3,230,000$ tons of $\mathrm{CO}_{2}$ [2]. In addition to this environmental problem, the Civil Works are not complying with the durability necessary to reach the useful life for which they were designed, with the main cause of their deterioration being the corrosion of the

Published on January 13, 2021

Laura Landa-Ruiz, Universidad Veracruzana, México.

(e-mail: lalanda@uv.mx)

Sabino Márquez-Montero, Universidad Veracruzana, México.

(e-mail: smarquez ${ }^{\circledR}$ uv.mx)

Griselda Santiago-Hurtado, Universidad Autónoma de Coahuila, México. (e-mail: grey.shg@ ${ }^{@ m a i l . c o m) ~}$

Victor Moreno-Landeros, Universidad Autónoma de Coahuila, México. (e-mail: vmmorlan ${ }^{\circledR}$ gmail.com)

José Manuel Mendoza-Rangel, Universidad Autónoma de Nuevo León, México.

(e-mail: jmmr.rangel@gmail.com)

Miguel Angel Baltazar-Zamora, Universidad Veracruzana, México.

(e-mail: mbaltazar@uv.mx) reinforcing steel used in reinforced concrete structures [3][9] a pathology that occurs mainly due to the exposure of sulfates [10], [11] or chlorides [12]-[15]. The corrosion of the steel in structures built on the basis of mechanically reinforced soils is of great importance in the structural integrity and durability of such works, as has been shown in some investigations [16], [17]. Industrial waste as Silica Fume, Fly ash, has been the subject of various studies in recent decades for its pozzolanic characteristics [18], [19], this wastes when used as partial substitutes for Portland Cement, concrete provides it with greater resistance against attacks from aggressive [20]. In the case of agro-industrial waste with greater potential due to its pozzolanic components [21], it is the SCBA, there are various works where it is used as a partial substitute for Portland Cement for the production of Ecological or Sustainable Concretes, where they have studied its effect on mechanical properties [22], as well as its durability [23]-[26]. In this research, the stabilization of a hydraulic-base type soil is evaluated with additions of sugar cane bagasse ash (SCBA) as a partial substitute for Portland cement, tests were carried out to determine the characterization and classification of the study soil was carried out, determining the Natural Humidity, Granulometric Curve, Consistency Limits, soil classification according to the USCS and AASHTO compaction. With the results obtained in the present investigation, it was verified that the use of CBCA as an addition in percentages of $5 \%$ and $7 \%$ improved the mechanical properties of the Hydraulic Base type material, which would contribute to the construction of roads with greater resistance, durability and sustainability, by making use of a waste that to date in Mexico, and even more so in the State of Veracruz, where a third of all the SCBA produced in the country is produced, the SCBA does not have a defined use, Considering just trash.

\section{MATERIALS AND Methods}

\section{A. Materials}

The hydraulic base material was obtained from the material bank located $20 \mathrm{~km}$ from the City of Xalapa. The cementitious materials used as additions were Portland Cement type CPC 30R [27] and Sugar Cane Bagasse Ash from (SCBA), which was obtained from Sugar Factory Mahuixtlán S.A. de C.V., located $5 \mathrm{~km}$ from to Coatepec, Veracruz, Mexico. 


\section{1) Characterization of study materials}

Geotechnical tests were carried out for the hydraulic base type of material (study soil) to determine the physical properties of the soil such as Natural Humidity, Granulometric, Consistency Limits as well as its classification according to the unified soil classification system (USCS) [28]-[30]. Chemical characterization of CBCA was also performed with the X-ray fluorescence analysis assay.

\section{2) Design of soil mixtures}

For the design of the mixtures, three percentages of Portland cement addition were established according to the classification of the material, as established by various technical prescriptions [31]. The percentages of addition materials were $5 \%$ and $7 \%$ with respect to the dry soil. Partial substitutions of Portland Cement for SCBA were also established in each previous percentage, of $0 \%, 25 \%, 50 \%$ and $75 \%$, having a total of 8 mixtures, as shown in table I. In addition, all the tests were carried out to the Hydraulic Base type soil in its natural state (Without any addition of $\mathrm{PC}$ or SCBA), to have it as a reference.

\begin{tabular}{ccccc}
\multicolumn{5}{c}{ TABLE I: Dosing OF ADDITIONS INTO THE SOIL } \\
\hline \hline \multirow{2}{*}{ Mixture } & $\begin{array}{c}\% \\
\text { Addition }\end{array}$ & $\begin{array}{c}\% \\
\text { PC }\end{array}$ & $\begin{array}{c}\% \\
\text { SCBA }\end{array}$ & PC-SCBA \\
\hline 1 & $5 \%$ & $100 \%$ & $0 \%$ & $100: 0$ \\
2 & $7 \%$ & & & \\
3 & $5 \%$ & $75 \%$ & $25 \%$ & $75: 25$ \\
4 & $7 \%$ & & & \\
5 & $5 \%$ & $50 \%$ & $50 \%$ & $50: 50$ \\
6 & $7 \%$ & & & \\
7 & $5 \%$ & $25 \%$ & $75 \%$ & $25: 75$ \\
8 & $7 \%$ & & & \\
\hline \hline
\end{tabular}

\section{B. Method}

\section{1) Compaction test}

The existing relationship of the maximum dry density and the optimal humidity of the soil-cement mixtures was determined in each of the percentages and at the partial substitutions of SCBA. By plotting the compaction curve, the compaction characteristics were obtained before setting the mixtures. For this compaction test, the conventional equipment for the modified AASTHO test was used, which consists of the mold with a volume of $2123+/-21 \mathrm{~cm} 3$, and the rammer weighing $4.54 \mathrm{~kg}$ with a diameter of $50.8 \mathrm{~mm}$ and a drop height of $45.7 \mathrm{~cm}$.

A sample of approximately $5 \mathrm{~kg}$ of dry material was conditioned, adding the Portland Cement and the SCBA to be used, and mixing the two materials. Small amounts of water are added, mixing thoroughly and allowing 5 min time to allow moisture absorption. Once the material is homogeneous, the points of the compaction curve are determined by applying the specified compaction energy.

\section{RESULTS AND DISCUSSION}

\section{A. Physical and Chemical Characterization of Materials}

According to what is established by the USCS, the soil of this study is it is a Poorly Graded Gravel with symbol GP.

Table II shows the results of the characterization of the soil under study that show the capacity of the soil to be used as a base layer material, complying with the characteristics of the $\mathrm{N} \bullet \mathrm{CMT} \bullet 4 \cdot 02 \bullet 002 / 11$ standard [32].

\begin{tabular}{cc} 
TABLE II: CHARACTERIZATION OF THE SOIL UNDER STUDY \\
\hline \hline Properties & Results \\
\hline Natural Humidity (\%) & $6.4 \%$ \\
Pass the 3 "mesh (\%) & $100 \%$ \\
Pass mesh No. 4 (\%) & $44.3 \%$ \\
Pass the 200 mesh (\%) & $4.9 \%$ \\
Liquid limit (\%) & $20.3 \%$ \\
Plastic Limit (\%) & $\mathrm{NP}$ \\
Plastic Index (\%) & $\mathrm{NP}$ \\
\hline \hline
\end{tabular}

Table III presents the chemical composition in oxides of the SCBA, it is observed that the sum of main oxides $\left(\mathrm{SiO}_{2}\right.$ $+\mathrm{Al}_{2} \mathrm{O}_{3}+\mathrm{Fe}_{2} \mathrm{O}_{3}$ ) gives a total of $85.994 \%$, ranking above $80 \%$ as established by the standard ASTM C-618 [33] for class $\mathrm{N}$ and $\mathrm{F}$ pozzolans and be used as supplementary materials. These results agree with those obtained in another research work where they used SCBA as a substitute material for Portland Cement [34].

\begin{tabular}{cc} 
TABLE III: CHEMICAL CHARACTERIZATION OF SCBA \\
\hline \hline Component & Concentration \\
\hline $\mathrm{SiO}_{2}$ & 77.739 \\
$\mathrm{Al}_{2} \mathrm{O}_{3}$ & 3.150 \\
$\mathrm{Fe}_{2} \mathrm{O}_{3}$ & 5.105 \\
$\mathrm{TiO}_{2}$ & 0.789 \\
$\mathrm{CaO}$ & 3.995 \\
$\mathrm{MgO}$ & 0.563 \\
$\mathrm{SO}_{3}$ & 0.406 \\
$\mathrm{~K}_{2} \mathrm{O}$ & 6.672 \\
$\mathrm{Na}_{2} \mathrm{O}$ & 0.569 \\
$\mathrm{P}_{2} \mathrm{O}_{5}$ & 1.673 \\
\hline \hline
\end{tabular}

\section{B. Results Maximum Dry Volumetric Weight}

In Figure 1 it can be observed that the maximum dry volumetric weight decreased its value when adding $5 \%$ and $7 \%$ of portland cement, as well as partially substituting cement for SCBA. The combination of $100 \%$ PC- $0 \%$ SCBA and $25 \%$ PC- $75 \%$ SCBA in the stabilizer percentage of $5 \%$ have similar values, which means that to use stabilizer at $5 \%$ of dry soil study the decrease in PC is possible. The $75 \%$ PC-25\% SCBA mixture had the lowest Maximum Dry Volumetric Weight of all the combinations; It can also be observed that at $7 \%$ stabilizer the MDVW gives similar values in all the combinations, except the $100 \%$ PC-O\% SCBA combination. The previous results agree with that reported by the literature [35].

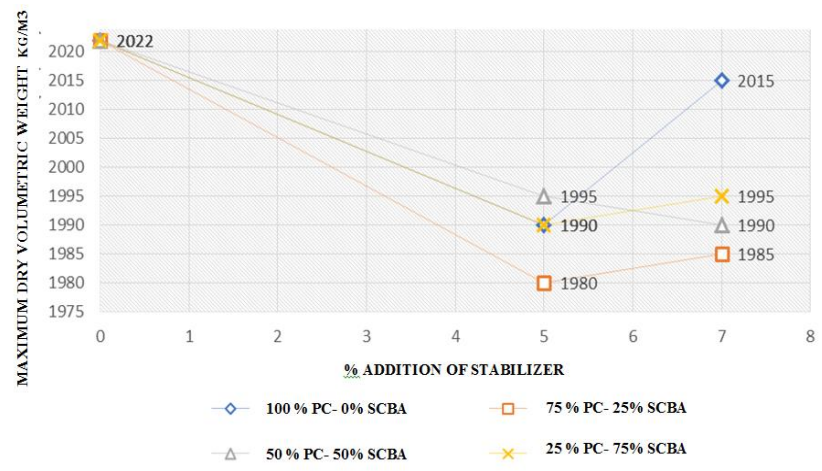

Fig. 1. MDVW behavior vs PC-SCBA combinations ( $\%$ of Stabilizer). 


\section{Results Optimal Humidity}

In Fig. 2 it is observed that the optimal compaction humidities increase when PC and SCBA are added, this due to the need to absorb a greater quantity of water due to the pozzolanic characteristics of both materials added to the soil. It is evident that the optimal humidities in the cases of 5 and $7 \%$ stabilizer are very similar, where the combination of $100 \%$ PC- $0 \%$ SCBA is the highest in both cases of $\%$ stabilizer, varying less than $2 \%$ between the major and minor.

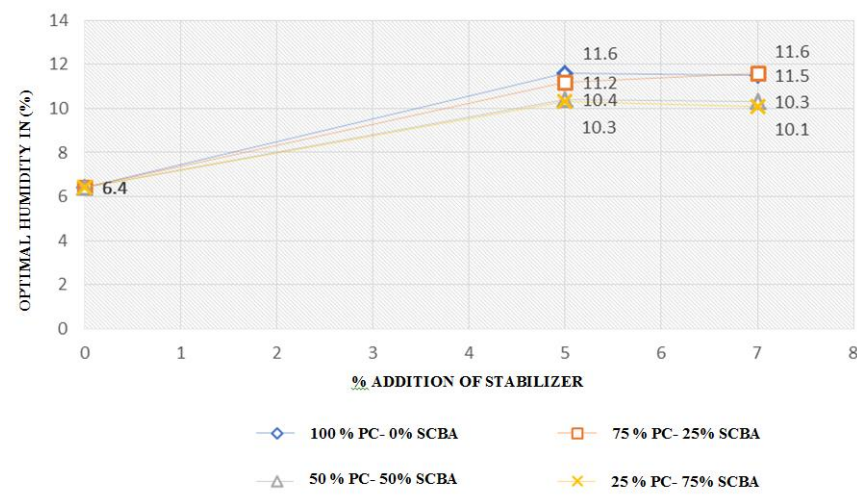

Fig. 2. Optimal Humidity Behavior vs PC-SCBA combinations (\% of Stabilizer).

\section{CONCLUSIONS}

In the Standard ASTM C-618, the physical-chemical composition of pozzolans established, specifies that class $\mathrm{N}$ and $\mathrm{F}$ pozzolans must add in their main oxides which are: Silicon oxide, Aluminum Oxide, and Iron Oxide $\left(\mathrm{SiO}_{2}+\right.$ $\left.\mathrm{Al}_{2} \mathrm{O}_{3}+\mathrm{Fe}_{2} \mathrm{O}_{3}\right)$ a percentage higher than $70 \%$ of its chemical composition. In the analysis, the sum of these main oxides is $85.058 \%$, which is why the SCBA complies as pozzolan.

The maximum dry volumetric weight increased in all the mixtures when substitutions of PC for SCBA were added, the combination of $100 \%$ PC-0\% SCBA being the most favorable in both cases with regard to compaction characteristics, since densities are obtained above those obtained in natural soil.

Optimum compaction humidity increases when PC is substituted for Sugar Cane Bagasse Ash, this phenomenon is attributed to the absorption of water by SCBA and PC during the compaction process. The maximum absorption is in substitutions of $100 \%$ PC.

The positive influence on the physical properties is verified by partially substituting SCBA for PC for stabilization or improvements in the properties of the Hydraulic Base and can be used as coatings on feeder roads, where there is no paving road infrastructure.

The partial substitution of SCBA for PC according to the results can be considered that it would contribute to more durable and therefore economical roads. In addition to contributing to the reduction in cement consumption, which would imply a decrease in the release of $\mathrm{CO}_{2}$ into the atmosphere due to the manufacture of Portland Cement.

\section{ACKNOWLEDGMENT}

MA Baltazar-Zamora, et. al., thank PRODEP for the support granted by the SEP, the Academicians UV-CA-458 "Sustainability and Durability of Materials for Civil Infrastructure" under the Call 2018 for Strengthening Academic Bodies with IDCA 28593. The authors thank A. Landa-Sanchez and C.E. Cuervo-Mendoza for the technical support.

\section{REFERENCES}

[1] Maria de Lourdes Olivo, Alejandra Soto-Olivo. (2010). Comportamiento de los gases de efecto invernadero y las temperaturas atmosféricas con sus escenarios de incremento potencial. UCT, Puerto Ordaz, 14:57, pp. 221-230.

[2] Informe estadístico 2013. (2013). Federación Interamericana del cemento. FICEM.

[3] A. Landa-Gómez et.al., (2018). Correlation of Compression Resistance and Rupture Module of a Concrete of Ratio w/c $=0.50$ with the Corrosion Potential, Electrical Resistivity and Ultrasonic Pulse Speed. ECS Transactions. 84, 217-227.

[4] M. Criado, D.M. Bastidas, S. Fajardo, A. Fernández-Jiménez, J.M Bastidas. (2011). Corrosion behaviour of a new low-nickel stainless steel embedded in activated fly ash mortars. Cement and Concrete Composites, 33, pp. 644-652.

[5] Miguel Angel Baltazar-Zamora, Sabino Márquez-Montero, Laura Landa-Ruiz, René Croche, Oscar López-Yza. (2020). Effect of the type of curing on the corrosion behavior of concrete exposed to urban and marine environment. European Journal of Engineering Research and Science, 5:1, pp. 91-95.

[6] O. Troconis de Rincón et. al., (2016). Reinforced Concrete Durability in Marine Environments DURACON Project: Long-Term Exposure. Corrosion, 72:6, pp. 824-833.

[7] G. Santiago-Hurtado et. al. (2012). Electrochemical Behavior of Reinforced Concrete and Its Relation with the Environment of Xalapa, Veracruz. International Journal of Electrochemical Science, 7:10, pp. 9825-9834.

[8] V. Volpi-León, L.D. López-Léon, J. Hernández-Ávila, M.A. BaltazarZamora, F.J. Olguín-Coca, A.L. López-León. (2017). Corrosion study in reinforced concrete made with mine waste as mineral additive. International Journal of Electrochemical Science, 12:1, pp. 22-31.

[9] D.M. Bastidas, M. Criado, S. Fajardo, A. La Iglesia, J.M. Bastidas. (2015). Corrosion inhibition mechanism of phosphates for early-age reinforced mortar in the presence of chlorides. Cement and Concrete Composites, 61, pp. 1-6.

[10] M.A. Baltazar-Zamora, G. Santiago-Hurtado, C. Gaona-Tiburcio et al. (2012). Evaluation of the corrosion at early age in reinforced concrete exposed to sulfates. International Journal of Electrochemical Science, 7:1, pp. 588-600.

[11] G. Santiago-Hurtado et. al. (2016). Electrochemical Evaluation of Reinforcement Concrete Exposed to Soil Type SP Contaminated with Sulphates. International Journal of Electrochemical Science, 11:6, pp. 4850-4864.

[12] M.A. Baltazar-Zamora, G. Santiago-Hurtado, V.M. Moreno L, R. Croche B, M. de la Garza, F. Estupiñan L, P. Zambrano R., C. GaonaTiburcio. (2016). Electrochemical Behaviour of Galvanized Stee Embedded in Concrete Exposed to Sand Contaminated with $\mathrm{NaCl}$. International Journal of Electrochemical Science, 11:12, pp. 1030610319.

[13] M.A. Baltazar-Zamora et. al. (2012). Efficiency of Galvanized Steel Embedded in Concrete Previously Contaminated with 2, 3 and $4 \%$ of $\mathrm{NaCl}$. International Journal of Electrochemical Science, 7:4, pp. 2997-3007.

[14] Miguel Angel Baltazar-Zamora, José Manuel Mendoza-Rangel, René Croche, Citlalli Gaona-Tiburcio, Cindy Hernández, Luis López, Francisco Olguín, Facundo Almeraya-Calderón. (2019). Corrosion Behavior of Galvanized Steel Embedded in Concrete Exposed to Soil Type MH Contaminated with Chlorides. Frontiers in Materials, 6, pp $1-12$.

[15] G. Santiago-Hurtado et. al. (2016). Electrochemical Evaluation of a Stainless Steel as Reinforcement in Sustainable Concrete Exposed to Chlorides. International Journal of Electrochemical Science, 11:4, pp. 2994-3006.

[16] Miguel Angel Baltazar-Zamora, Laura Landa-Ruiz, Yazmin Rivera, René Croche. (2020). Electrochemical Evaluation of Galvanized Steel 
and AISI 1018 as Reinforcement in a Soil Type MH. European Journal of Engineering Research and Science, 5:3, pp. 259-263.

[17] G. Santiago-Hurtado, M.A. Baltazar-Zamora, A. Galindo D, J.A Cabral M, F.H. Estupiñán L., P. Zambrano Robledo, C. GaonaTiburcio. (2013). Anticorrosive Efficiency of Primer Applied in Carbon Steel AISI 1018 as Reinforcement in a Soil Type MH. International Journal of Electrochemical Science, 8:6, pp. 8490-8501.

[18] M.L. Berndt. (2009). Properties of sustainable concrete containing fly ash, slag and recycled concrete aggregate. Construction and Building Materials, 23:7, pp. 2606-2613.

[19] K. Shi-Cong, P. Chi-Sun. (2013). Long-term mechanical and durability properties of recycled aggregate concrete prepared with the incorporation of fly ash. Cement and Concrete Composites, 37, pp. 12-19.

[20] M.A. Baltazar-Zamora, D.M. Bastidas, G. Santiago-Hurtado, J.M. Mendoza-Rangel, C. Gaona-Tiburcio, J.M. Bastidas, F. AlmerayaCalderón. (2019). Effect of Silica Fume and Fly Ash Admixtures on the Corrosion Behavior of AISI 304 Embedded in Concrete Exposed in 3.5\% $\mathrm{NaCl}$ Solution. Materials (Basel), 12:23, pp. 1-13.

[21] M.K. Yashwanth, B.G. Naresh Kumar, D.S. Sandeep Kumar. (2019). Potential of Bagasse Ash as Alternative Cementitious Material in Recycled Aggregate Concrete. International Journal of Innovative Technology and Exploring Engineering, 8:11, pp. 271-275.

[22] Laura Landa-Ruiz, Hilda Ariza-Figueroa, Griselda Santiago-Hurtado, Victor Moreno-Landeros, Raul López Meraz, Rafael Villegas-Apaez, Sabino Márquez-Montero, René Croche, Miguel Angel BaltazarZamora. (2020). Evaluation of the Behavior of The Physical and Mechanical Properties of Green Concrete Exposed to Magnesium Sulfate. European Journal of Engineering Research and Science, 5:11, pp. 1353-1356.

[23] A. Landa-Gómez et.al., (2018). Corrosion Behavior 304 and 316 Stainless Steel as Reinforcement in Sustainable Concrete Based on Sugar Cane Bagasse Ash Exposed to $\mathrm{Na}_{2} \mathrm{SO}_{4}$. ECS Transactions. 84, pp. 179-188.

[24] Miguel Angel Baltazar-Zamora, Hilda Ariza-Figueroa, Laura LandaRuiz, and René Croche. (2020). Electrochemical Evaluation of AISI 304 SS and Galvanized Steel in Ternary Ecological Concrete based on Sugar Cane Bagasse Ash and Silica Fume (SCBA-SF) exposed to $\mathrm{Na}_{2} \mathrm{SO}_{4}$. European Journal of Engineering Research and Science, 5:3, pp. 353-357.

[25] Hilda A. Ariza-Figueroa et. al. (2020). Corrosion Behavior of AIS 304 Stainless Steel Reinforcements in SCBA-SF Ternary Ecologica Concrete Exposed to $\mathrm{MgSO}_{4}$. Materials (Basel), 13:10, pp. 1-16.

[26] Abigail Landa-Sánchez et. al. (2020). Corrosion Behavior of SteelReinforced Green Concrete Containing Recycled Coarse Aggregate Additions in Sulfate Media. Materials (Basel), 13:19, pp. 1-22.

[27] NMX-C-414-ONNCCE 2014: Cementantes Hidráulicos. ONNCCE, S.C.; Mexico 2014

[28] $N M X-C-416$ ONNCCE-2003- Muestreo de estructuras terreas y métodos de prueba. ONNCCE S.C., México, (2003).

[29] B.M. Das. Principio de Ingeniería de Cimentaciones. pp. 68-71. Ed. Thomson, México, (2006).

[30] M.MMP.1.04/03 Métodos de muestreo y prueba de materiales. Suelos y materiales para terracerías. Contenido de Agua. S.C.T.,México, (2004)

[31] Jofre, C., Kraemer, C., Sampedro, A., Lopez Bachiller, A., Atienza, M., Diaz, M., et. al. (2008). Manual de estabilización de suelos con cemento o cal. Madrid: Instituto Español del cemento y sus aplicaciones.

[32] N. CMT.4.02-002/11. Materiales para pavimentos. Materiales para Subbases y Bases. Materiales para Bases Hidráulicas. S.C.T., México, (2004).

[33] ASTM C-618-19. Standard Specification for Coal Fly Ash and Raw or Calcined Natural Pozzolan for Use in Concrete; ASTM International, West Conshohocken, PA, 2019, www.astm.org.

[34] Elisabeth Arif, Malcolm W. Clarka, Neal Lake. (2017). Sugar cane bagasse ash from a high-efficiency co-generation boiler as filler in concrete. Construction and Building Materials, 151, pp. 692-703.

[35] O. Ojeda-Farías, J.M. Mendoza-Rangel, M.A. Baltazar-Zamora. (2018). Influence of sugar cane bagasse ash inclusion on compacting, CBR and unconfined compressive strength of a subgrade granular material. Revista ALCONPAT, 8:2, pp. 194-208. 